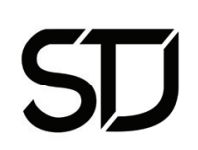

\title{
Moral earthquakes and our response: Can ethics make a difference?
}

\author{
Richardson, RN \\ University of KwaZulu-Natal \\ neville.richardson@airedalemethodists.org
}

\begin{abstract}
.
The major conflicts that shake our world are often driven by deep seated religious and cultural differences - they seem so overwhelming and run so deep that a seismological metaphor seems appropriate. How can ethics help to resolve these conflicts when much twentieth century ethical theory understood its role to be "neutral as regards actual conduct"? Alasdair MacIntyre rightly criticised the ethics of the Enlightenment project, but his own positive proposals do not seem to offer a clear way to address major moral conflicts. Can Christian ethics and the Christian church play a constructive role in our multi-faith and multicultural world? A practical ecumenical proposal is considered and is seen to offer a bridge across the theory-action divide; to draw together some positive suggestions of MacIntyre and other socio-ethicists; and to foreground the important role that the church might play in responding to major moral conflicts.
\end{abstract}

\section{Keywords}

Moral conflict, ethical theory, Alasdair MacIntyre, Christian ecumenical ethics.

In April 2015 an earthquake struck Nepal. It shook the world's greatest mountain range, caused avalanches which swept away teams of mountaineers, destroyed towns and killed many thousands, leaving observers feeling helpless and impotent. It is little wonder that a prescientific age saw such literally earthshattering events in theological terms and turned their eyes to God for help. God caused it and God alone could fix it.

- You have rejected us, God, and defeated us;

- You have been angry with us - but now turn back to us. 
- You have made the land tremble, and you have cut it open;

- Now heal its wounds, because it is falling apart. ${ }^{1}$

Has modern scientific and technological knowledge made earthquakes any less terrifying and destructive? What possible difference can human agency make when the problem lies in shifting tectonic plates miles below the earth's surface? Advanced seismological research can try to explain in retrospect what has happened, but is nowhere near being able to predict and warn where the next earthquake will happen, and even less able to prevent such catastrophes. Of what practical use is that?

This is not a article on seismology, but on ethics, specifically theological ethics. The earthquake metaphor describes the moral experience in the modern global world where vast tectonic plates of moral and cultural allegiance and conviction sometimes coexist but at other times shift and collide with devastating effect. Not least are the forces that respect and revere individual freedom of expression to the extent of belittling religions and humiliating believers, and those counterforces that seem to approve of brutal reprisals, public beheadings, suicide bombings and other dramatic acts of deadly violence. These different blocks of opinion are often given religious labels, even by the agents themselves who call themselves by names such as "Islamic State". News reports bring a sharpened sense of helplessness and impotence on the part of those who feel some kind of moral outrage or responsibility - a wringing of the hands and a cry of despair: "What can we do?"

Major moral conflicts occur not only between religions but also within religions. The historic doctrinal differences which gave rise to the major schisms in most faith communities were seldom matters of pure doctrine alone. They were entwined in struggles of politics, economics and power. Currently, within Islam, Sunni and Shia groups often come into deadly conflict. Christianity has certainly not been immune to such conflicts. The Reformation and the five ensuing centuries have seen Christian factions in conflict with each other - conflict that has sometimes become violent and deadly. Currently there is a major division within world Christianity

1 Psalm 60: 1-2. In Good News Bible: Today's English Version (London: The British \& Foreign Bible Societies, 1976). 
over attitudes to same sex relationships. Conservative Christians regard same sex relations as "an abomination" and are adamant that their view is grounded in biblical authority. Liberal Christians do not disregard the Bible (as Conservatives often assume they do), but also take account of modern understandings of human sexuality as much more complex than was previously thought, and they see the spirit of Jesus to be accepting of people who are "on the margins". At present it is difficult to see how these tectonic plates of Christian moral conviction could come together peacefully. If the Christian churches cannot bridge their own moral fault lines, how are they to help with those of the wider societies in which they operate and of which they are a part?

Major moral conflicts also occur when different cultures collide, as they often do in multicultural societies like South Africa. Churches there are aware of the tension between Eurocentric and Afrocentric theology and practice. A dramatic account of a collision of cultural perspectives is Gavin Hood's 1999 film, A Reasonable Man. In the film a small child is stabbed to death in rural Kwazulu-Natal and the acknowledged perpetrator must face the full force of the law. But the law is a western construction and he is a young rural Zulu man. His defence is not to deny the killing, but to deny that what he killed was a human child - in his perception it was a tokoloshe, an evil spirit which brought danger to himself and his family. According to his tradition such a killing would be justified, but how could the judge take account of that? How are such dramatic differences to be reconciled in law without the law itself becoming yet another morally complicating factor? Can the Christian churches play a bridging role, perhaps even a healing role in cultural and legal conflicts of this kind? Believing as they do in a God of all the earth and of all people, of all living things and the whole environment should they feel an obligation in that regard? Or is such an obligation simply an exercise in frustration?

\section{The plight of modern ethics}

Many of those who have involved themselves in the study of ethics for large parts of their professional lives, would love to be able to produce clear answers to help solve major moral conflicts such as these, but their experience is often that of frustration and even futility. Instead of being able to uncover some principle of such self-evident moral power that all 
must agree or at least find common ground for discussion; instead of trumpeting a proof text that points to only one road ahead for all, we find ourselves as impotent as seismologists trying to guess the time and place of the next great earthquake. Why is this the case, and is there anything to be done about it?

Much of the energy of moral philosophers in the twentieth century was spent on debates about ethical theory which ended up in a kind of intellectual outer space. Their "meta-ethics" seemed to have little to do with the moral life itself. Their efforts led them to what seems to have been "a distant galaxy far, far away", as in the statement (confession?) of A.J. Ayer who declared: "All moral theories... are neutral as regards actual conduct." He explained: "To speak technically, they [moral theories] belong to the field of meta-ethics, not ethics proper." ${ }^{2}$ But such a separation of metaethics from ethics only serves to deepen the frustration. How does "metaethics" relate to "ethics proper", and how does "ethics proper" relate to "actual conduct"?

Another twentieth century moral philosopher, RM Hare, recognised the futility of this line of thought. His response was:

If ethical theories are neutral as regards actual conduct - if judgements of value can have no logical connection with such a theory - then what is the point of ethics? This is, as I have said, a question which is frequently asked, not only about Ayer's work, but about that of other ethical writers at the present time; I have more than once been asked it myself, in a somewhat hostile spirit. It is a question that anyone must face who holds that ethics is concerned with the analysis of moral concepts. ${ }^{3}$

Did Hare then put forward a more helpful proposal? He drew on the Kantian notion of moral universals - the idea that there are fundamental moral duties and principles, like justice, that are somehow known to each moral agent irrespective of historical or cultural or religious or any other influencing factors. At some point in moral deliberation, everyone in every situation

2 AJ Ayer, Philosophical Essays (London: Macmillan, 1954), 256.

3 RM Hare, Essays on Philosophical Method (Berkeley and Los Angeles: University of California Press, 1971), 12. 
should know what is meant when a principle like justice is discussed. The requirement for such principles and values, and indeed Hare's requirement for qualification as a moral principle, was "universalizability".

This sounds hopeful, does it not? Here, surely, is ethics which is ready for action in the world of moral challenges and problems. Here is ethics which should act as a catalyst in promoting understanding between people and setting those moral tectonic plates of the modern global world at rest. But how much help can this approach offer in a conflict as deep and wide as the cultural chasm in A Reasonable Man? How much can it help the international community with its great ideological conflicts? How much can it help the church in its damaging divisions over sexuality? There is often a lurking suspicion that different groups simply do not share the same understanding of moral concepts and principles. Conflicting understandings of what constitutes justice, for instance, deepen the gulf that separates them. Are there alternative voices to be heard on ethics?

\section{MacIntyre's critique and proposal}

One of the leading voices expressing frustration with the approach just described is Alasdair MacIntyre. In his view, the ethics proposed by those like Hare and all like him who follow the Enlightenment model, is seriously flawed at many levels. It separates facts from values and theory from practice. In practice, it is found that moral concepts and judgements differ widely between individuals, communities, ideologies and religions. In order to establish common ground ethical concepts must be spread so thin and be presented in generalities so abstract as to be divorced from moral experience. It holds that in order to know the required principles and values, moral agents must be detached from any subjective influencing factors to the extent that they become lifeless shells with no personal history or experience. The moral terms in which such hope and confidence are placed are themselves deeply problematic when we come to apply them or use them in intercultural or legal situations. Even within Western culture they may sound as though they should provide clarity, but they are only hollow echoes of what they once were, and what we imagine they still are. 
We possess indeed simulacra of morality, we continue to use many of the key expressions but we have - very largely, if not entirely - lost our comprehension, both theoretical and practical, of morality.

There have been attempts to defend and rescue the ethics of the Enlightenment model, largely in response to MacIntyre's critique of ethical "liberalism". ${ }^{5}$ But whoever wins this debate, it seems to end in a theoretical cul de sac. What is achieved beyond the scoring of theoretical debating points? How are we then to proceed in the face of conflicting moral viewpoints, commitments and cultures? If we turn rather to MacIntyre's positive proposals, can they provide a way forward?

MacIntyre insists that for our moral terminology to be coherent it must be rooted in some particular moral community. Moral terminology and concepts must describe demonstrable practices. Our morality must be learned and moral learning can take place only in a moral community. In such communities there are respected traditions and authoritative people passing on key practices and skills to others. As fledgling moral agents we must consciously belong to a particular community in which we can learn morality as an apprentice learns a skill at the hand of a master. Learning to be a moral agent, however, is more than merely learning practices and skills and language. It is a matter of developing moral character. It is only through such communities that human individuals can be shaped morally, so that they are able to see and know and judge morally - to have moral wisdom. With this learned skill and moral wisdom comes the ability to communicate about morality with others in our community. They, in turn, should be able to pass on their moral knowledge to those who follow them. What is passed on may include values and principles, laws, rules and a consideration of likely consequences, but more than these ethics is about virtues, and virtues find their place in moral character which, in turn, is located in moral community. The influence of Aristotle is clear!

4 Alasdair MacIntyre. After Virtue, $2^{\text {nd }}$ ed. (Notre Dame: University of Notre Dame Press, 1984) 5. In chapter 5 he provides a thoroughgoing critique of what he calls "the Enlightenment project".

5 See Thaddeus Kozinsky's discussion of Jeffrey Stout's "Pragmatic Liberalism" (which grants a limited role to tradition), and his discussion of "Honest Pragmatic Liberalism" ("honest", because it is prepared to acknowledge the exclusion of radical countervoices), in Thaddeus J Kozinsky, "Alasdair MacIntyre vs. Pragmatic Liberalism," Telos 143 (Summer 2008): 7-21. 
MacIntyre's account seems down to earth in comparison with the ethics described above, which he sees as part of the "Enlightenment project". We recognise the moral experience he describes - our learning from others, both positively and negatively, and being shaped as we interact with others in community. One is reminded of the African proverb: "It takes a village to raise a child." We can see how ethics would work in communities, including Christian communities and it is a particular Christian tradition that is at the foreground of MacIntyre's moral vision - specifically the Thomist tradition in Roman Catholicism.

Yet MacIntyre's proposals, while seeming to present a more grounded account of the human moral experience, also present difficulties. One difficulty is that we do not belong in single, unified communities, but have multiple belongings, many of which overlap with each other and some may have a very different moral ethos from the others. How do we then decide which one is to have the authority to shape us and teach us the virtues we need, or do we become moral schizophrenics struggling to operate with conflicting moral priorities and identities? Perhaps in the medieval times which seem to be the focus of MacIntyre's historical and social perspective communities were more simple and unified, but even then there must have been layers of communal belonging. Certainly in the modern global world, we find ourselves in highly complex social networks. This points to an even greater difficulty. MacIntyre's communities seem to be moral silos and it is not easy to see how there might be any communication or interaction between the various moral communities.

On the level of moral theory, MacIntyre has drawn heavy lines of difference between the most influential moral theories in modern Western thought. These he names Encyclopaedia, Genealogy and Tradition. ${ }^{6} \mathrm{He}$ stresses that these three versions of moral theory cannot understand each other. His key terms here are "untranslatability" and "incommensurability" which reinforce the image of moral silos. It is as though they cannot hear each other speak and, even if they could, they would not understand each other. It would be as if they were speaking in foreign languages. And so, at the level of moral theory we are back at our problem of the tectonic plates

6 Alasdair MacIntyre, Three Rival Versions of Moral Enquiry: Encyclopaedia, Genealogy and Tradition (Notre Dame: University of Notre Dame Press, 1990). 
that threaten to collide with destructive effects. By rescuing ethics from the abstraction and individualism of Enlightenment thinking, by bringing moral communities back into focus, and by bridging the theory-action divide, MacIntyre has made a valuable contribution to ethics, but he does not help us when we are faced with problems of a legal nature in intercultural societies where between different cultures the same action may be regarded as simultaneously criminal and justified. He certainly does not help us in matters of global conflict of ideologies. He does not even help us within the Christian tradition with its current conflict between viewpoints over sexuality. Terms like "untranslatable" and "incommensurable" serve only to heighten the sense of the futility of ethics in a dangerously divided world. The burning question is how the traditions and cultures might relate to each other.

\section{Pointers towards solutions}

To his credit, MacIntyre is aware of the difficulties his theory generates and he tries to address them. He defends his theory by entertaining the possibility of those in rival traditions understanding and communicating with each other but acknowledges that this would not be straightforward and that it would bring challenges and changes.

A precondition of the adherents of two different traditions understanding those traditions as rival and competing is of course that in some significant measure they understand each other. This understanding is sometimes to be achieved only by a set of related historical transformations; either or both of the traditions may have had to enrich itself significantly in order to be able to provide a representation of some of the characteristic positions of the other, and this enrichment will have involved both conceptual and linguistic innovation, and quite possibly social innovation too. ${ }^{7}$

7 Alasdair MacIntyre, Whose Justice? Which Rationality? (London: Duckworth, 1988) 370. For an excellent discussion on the desirability of change in traditions, with reference to Reformed theology in South Africa, see Robert Vosloo, "Reforming tradition: remarks on reformed theology in South Africa, in conversation with Alasdair MacIntyre," Journal of Theology for Southern Africa 139 (March, 2010), 18-31. 
He enlarges on the idea of "linguistic innovation" by speaking in terms of learning each other's languages. This seems to mean more than a mechanical conveying of meanings, but also the mutual communicating of cultures. He describes how a child learns a language not by matching meanings as adults tend to do, but by absorbing an entire culture along with the words. To learn another language like a child is to learn "a second first language". ${ }^{8}$ This is in effect what anthropologists aim for when they live in another culture in order to understand it.

Obviously this process of language learning is best understood in the case of those who, like anthropologists in training, go to live in the society of the other culture and transform themselves, so far as is possible, into native inhabitants. ${ }^{9}$

Clearly the conceptual, linguistic and social innovations all work together in the task of mutual understanding. But while it is relatively easy to speak in theory of such "enriched" traditions and cultures, the practicalities of achieving this are dauntingly complex. How are we to go about achieving such enrichment?

More wide ranging in terms of the varieties of intercultural interaction and more sociological in their emphasis are the proposals of Richard Evanoff. He regards MacIntyre as too retrospective, whereas he is committed to being more future-orientated. Of his own approach Evanoff says:

In this view, then, the issue is not so much maintaining continuity with past traditions, as MacIntyre holds, but rather having the ability to "let go" of one tradition and to actively participate in the creation of an entirely new one. The "new tradition" may not maintain continuity with any one tradition but perhaps with several. ${ }^{10}$

Evanoff's stated aim is to describe and encourage a process of integration which goes beyond mutual respect or even adaptation. His vision is for the development of "third cultures" in which positive aspects of the cultures

8 MacIntyre. Whose Justice? 374.

9 MacIntyre. Whose Justice? 374.

10 Richard Evanoff, "Integration in Intercultural Ethics," International Journal of Intercultural Relations 30 (2006): 424. 
in dialogue are integrated in new and creative ways. He concludes by acknowledging MacIntyre but simultaneously looking beyond him.

While there may in fact be norms held by different cultures which are truly incommensurable, and therefore not susceptible to integration, it is nonetheless possible that new norms can be created in cross-cultural encounters which integrate values from the respective cultures and enable the participants to deal more effectively with problems of mutual concern. ${ }^{11}$

Does this provide us with a helpful, practical way forward? Much surely depends on the pronouns "we" and "us", and whether there is anything in our culture and tradition that is indeed incommensurable with others.

\section{A practical ecumenical proposal}

MacIntyre's stress on community as a necessary embodiment of virtues and a base for ethics, and his awareness of the need for "social enrichment" of societies through interaction with other societies raise practical questions as to how such interaction should take place. A further question concerns the scope of this approach - how many communities are we talking about? From the perspective of Christian faith and practice, the widest possible scope for intercultural interaction is probably that described by the term "ecumenical". In this regard Josef Smolik's suggestions about community from a Christian ecumenical perspective are worth considering. ${ }^{12}$

In the context of his native Czechoslovakia in the early 1980s Smolik reflects on the term koinonia in its ecumenical usage. ${ }^{13} \mathrm{He}$ argues from basic ecumenical principles, reminding us that the term oikoumene means the whole inhabited earth and that it strongly implies all living together as a whole. He examines the experience of trying to live together and is

11 Evanoff, "Intercultural Ethics", 435.

12 Josef Smolik, "Ecumenism as Living Together", in Pauline Webb, ed. Faith and Faithfulness: Essays on Contemporary Ecumenical Themes (Geneva: World Council of Churches, 1984), 61-70.

13 There is an irony in Smolik's proposals for deepened unity, in that his own nation which was established in October 1918, divided into the Czech Republic and Slovakia at the beginning of 1993. His passionately expressed suggestions, however, hold good for communities and churches in general. 
aware of its complexity and difficulty. He first questions the arrogance of Western attitudes which envisage one global culture which happens to be Western culture. He points out the obvious error of such a view, given the catastrophic events in Europe in the twentieth century and recounts the marginalization he and others from the non-English speaking world often feel in ecumenical meetings. But he does point to "a common basis" which transcends barriers of language and culture and makes genuine dialogue possible.

What is this common basis? Anyone who has taken part in encounters at ecumenical consultations, especially the smaller kind of consultations, will know that it is no mere pious phrase when I say that this common basis has been faith in the same Lord Jesus Christ, the same gospel. The astonishment with which we have recognised that, despite different ideologies, different histories and confessions, we have the same gospel, even if we are able to discuss it only haltingly together, has been overwhelming. That gospel which has been common to us was not a doctrine but love and mutual acceptance as brothers and sisters together in faith. All cultural and traditional prejudices or suspicions have been set aside as secondary in comparison with this common ground. In Jesus Christ we have rediscovered our true humanity created by God. This humanity binds us with all people - including atheists - and makes true dialogue possible. ${ }^{14}$

In speaking of a common basis which transcends cultural and linguistic barriers, Smolik seems to be leaning toward the Enlightenment notion of shared universal principles. Conversely, in his sensitivity to the unavoidable cultural, historical and ideological particularities of background, he seems to be leaning in MacIntyre's direction. As he continues, he seems to look toward the possibility of Evanoff's "third cultures". Most positive and encouraging is his regard for other cultures and traditions not as some ever-present nuisance to be endured and dealt with, but as a source of great enrichment. He quotes from the statement of the 1975 Assembly of the WCC in Nairobi.

14 Smolik, "Ecumenism as living together", 63-64. 
We have found this confession of Jesus Christ out of our various cultural contexts to be not only mutually inspiring but also a mutually corrective exchange. Without this sharing, our mutual affirmations would gradually become poorer and narrower. We need each other to regain the lost dimensions unknown to us before. Sharing in this way we are all changed and our cultures are transformed. ${ }^{15}$

Could this be the kind of integrative engagement with which both MacIntyre and Evanoff could agree? It speaks of cultures as poorer without such interaction and by implication enriched through it, precisely as MacIntyre suggested. It acknowledges the mutual correction and transformation experienced by participants, a necessary aspect of MacIntyre's moral learning. It is positively inclined towards the creative development of new cultures as Evanoff urges.

Smolik, however, is keenly aware of potential pitfalls, especially where there are economic imbalances. The danger of the donor-dependency relationship, for example, is a frequent undesirable accompaniment in missionary and ex-missionary contexts. In this regard Smolik confidently claims that true Christian koinonia "shatters and transcends the relationship of donor and receiver" ${ }^{16}$ It is to be hoped that his confidence in the gospel and the Holy Spirit to transform power into a means of unselfish service is justified. Disciples of Nietzsche and Foucault would probably have serious doubts about this, but their suspicion could be used to alert and sensitize participants to the ever-attendant pitfalls of power relations.

Finally, and very hopefully, Smolik recalls the ecumenical commitment to world peace, and in living together to this end. He holds up the biblical vision of peace as "not one of several options for the followers of Christ", but as "an imperative in our time". ${ }^{17}$ What does this imperative require from ecumenical Christians?

Living together in ecumenical fellowship requires us to stress what we have in common as Christians, and to refuse to let ourselves be

15 Smolik, "Ecumenism as living together", 64.

16 Smolik, "Ecumenism as living together," 67.

17 Smolik, "Ecumenism as living together," 69. 
divided by the external tensions of our time....the churches and the ecumenical movement can be of real help to this world only when they share life together dynamically - and are more than just an organization located in Geneva - awaiting the coming Lord and kingdom. Nowadays the churches are being forced to discover their role as the Body of Christ, the Servant of the Lord, and what the Third Assembly of the WCC called a 'pilgrim church' which goes forth boldly as Abraham did into the unknown future, not afraid to leave behind the securities of its conventional structures, glad to dwell in the tent of perpetual adaptation, looking to the city whose builder and maker is God. ${ }^{18}$

Three observations must be made on Smolik's helpful and inspiring suggestions. First, while his scope is truly ecumenical and his concern is for the whole of the inhabited universe, his address is to a particular community and the language he uses is that of a particular community - that of modern ecumenical Christianity. He makes it clear that faith in Jesus Christ and sharing in a common gospel are not incidental, but essential to the ecumenical vision. This "common basis" of which he speaks is the source of his ecumenical way of seeing the world. A MacIntyrean view would go further and point to an even more specific community from which and for which Smolik speaks. It is the "Life and Work" strand within the ecumenical movement. In its early phase of development, in the first half of the twentieth century, the ecumenical movement divided its work institutionally into two main streams: "Faith and Order" and "Life and Work". The Faith and Order stream worked on matters of doctrine and aimed to achieve doctrinal agreement among the participating denominations, while Life and Work reacted against the notion that unity could be achieved through doctrinal agreements. Its slogan was: "Doctrine divides, service unites". ${ }^{19}$ Smolik's Life and Work roots are fully visible when he says: "That gospel which has been common to us was not

18 Smolik, "Ecumenism as living together," 69-70.

19 The Life and Work movement held a landmark conference in Stockholm in 1925 at which the Swedish Lutheran Archbishop Nathan Söderblom was a key figure: “...his aim being to organise the practical co-operation of the Christian Churches esp. in social questions without consideration of doctrinal differences." The Oxford History of the Christian Church, ed. F.L. Cross (Oxford: Oxford University Press, 1958), 1267. 
a doctrine but love and mutual acceptance as brothers and sisters together in faith." ${ }^{20}$ To draw this methodological and institutional distinction too firmly, however, would run counter to the purpose of this article and would serve to reinforce the theory-practice dichotomy of Enlightenment ethics which this article has, with MacIntyre, rejected. In similar vein John de Gruchy has helpfully endorsed the "earthy spirituality" which springs from the ecumenical vision, which "rejects the dualisms both of modernity and of those forms of Christianity which separate piety and social action". ${ }^{21}$

Second, it needs to be asked what level of "living together" Smolik has in mind. He seems perfectly explicit in his call for interaction at more than merely the institutional level of ecumenical meetings. But human community is complex and moves at many levels right down to that of families and individuals. Does he have in mind individual church congregations, and even families somehow joining together on a daily basis? There can be no general answer to such questions, but it is here that the principal of subsidiarity becomes important. That is, while "living together" should operate at all levels of society, it is the smallest and most local that should take priority. In practice, this is also at this level at which social interaction is probably most detailed and challenging!

Third, Smolik seems to be reaching more for the future than seeking to preserve continuity with the past. In this he seems to satisfy the requirements of Richard Evanoff who, as we saw, encourages letting go of past traditions in order to participate in the creation of an entirely new "third culture". There is, however, a vital difference between Smolik and Evanoff. For Evanoff the "letting go" of past traditions seems to be absolute and without remainder. It seems certain that Smolik, as an ecumenical Christian, could not agree with that. As noted above, the basis for his ecumenical vision is his Christian faith and belonging. There is a fine distinction to be made here concerning one's attachment to one's religion, culture and tradition. Clearly too tight a grip will hinder any attempt to be open to genuine intercultural understanding - this is Evanoff's criticism of

20 Smolik, "Ecumenism as living together," 64. The Life and Work slogan "Doctrine divides, service unites", was sometimes expressed as "Doctrine divides, love unites".

21 John de Gruchy, "Recovering ecumenical vision and commitment in a post-ecumenical era," Journal of Theology for Southern Africa 102, (November, 1998): 1-12. 
MacIntyre. Conversely, too loose a grip leaves one with nothing distinctive to contribute to the interaction, as well as to an incoherent understanding of morality - this would be MacIntyre's criticism of Evanoff.

How can there be a "letting go" while still preserving continuity? Perhaps the key to this conundrum is to be found in our view of language. What language would be used in Evanoff's entirely new "third culture"? Would it include the creation of an entirely new language, perhaps containing some elements of the languages of the previous traditions - a new kind of Esperanto? While Smolik may be open to such a suggestion, he would need assurance that the language of his Christian faith would not be compromised. Both he and MacIntyre would find such assurance in the following comment:

Moreover, if we are confident Christian speakers we may well discover that there are other languages that have words and grammars we can use. After all, Christian speech has been and will continue to be forged from encounters that have resulted in Christian appropriation of other ways of speaking that help us be faithful to the gospel. ${ }^{22}$

Yes, life in the modern intercultural, interfaith global world presents us with an ethical demand to develop new "second first languages", but not at the expense of our Christian mother tongue.

\section{Conclusion}

At the start, this article urged that ethics, especially Christian ethics, should be of real use in the face of the major moral conflicts of our time. It registered frustration with the abstraction of much ethical theory in the twentieth century and noted that even MacIntyre's debunking of that earlier approach recognises the need for genuine interaction between vastly different traditions, ideologies and cultures. It also enquired how the church might be helpful in this struggle and this seems to be precisely what Smolik envisions. His claim is that "the churches and the ecumenical

22 Stanley Hauerwas, Learning to Speak Christian (London: SCM, 2011), 92. 
movement can be of real help to this world only when they share life together dynamically". ${ }^{23}$

It may be objected that this article wanders between the theoretical and the practical, as is evident in the previous paragraph. Not only is this "wandering" deliberate, but it stands as a protest against the dichotomy of ethical theory and practice, and any understanding of ethics as being "neutral as regards actual conduct". It seeks for faith and action to be in dynamic interaction with each other in the search for an adequate Christian ethical approach to conflicting communities, cultures, traditions and ideologies.

Just as the massive subterranean tectonic plates which clash and cause earthquakes may be solid and impermeable and beyond the present capability of human technology to control, it seems that there will always be those who choose the way of division and conflict in human affairs. Yet human interactions also carry different, more peaceful and constructive possibilities and it is to these that Smolik's suggestions point. As people from different backgrounds commit to living together the rock of their differences may be found to be more permeable, more flexible and more malleable than previously anticipated.

Of course, immersion in different cultures and traditions is unlikely to be practically possible for the mass of the people, just as all cannot be anthropologists setting out to live in foreign cultures. Not all Christians may be willing to accept the changes required of them, forgetting that radical personal transformation is at the heart of our faith (2 Corinthians 5:17). Furthermore, those who do commit to interfaith and intercultural engagement, to developing a second first language and who accept the changes in themselves, must take on an extra moral obligation. They will have to carry their learnings and insights back to their original communities and communicate their findings so that others can learn and follow in their footsteps, so that personal transformation may become social transformation. Progress towards mutual understanding and harmony and peace will inevitably be slow and the changes at times imperceptible, but at least there will be in place a moral process offering significant help in the face of the great moral conflicts of our time.

23 Smolik, "Ecumenism as living together," 69. 


\section{Bibliography}

Ayer, AJ. Philosophical Essays. London: Macmillan, 1954.

Cross, FL (Ed.). The Oxford History of the Christian Church. Oxford: Oxford University Press, 1958.

De Gruchy, John. "Recovering ecumenical vision and commitment in a post-ecumenical era," Journal of Theology for Southern Africa 102 (November, 1998): 1-12.

Evanoff, Richard, "Integration in Intercultural Ethics," International Journal of Intercultural Relations 30 (2006): 421-437.

Hare, RM. Essays on Philosophical Method. Berkeley and Los Angeles: University of California Press, 1971.

Hauerwas, Stanley. Learning to Speak Christian. London: SCM, 2011.

Good News Bible: Today's English Version. (British edition). London: The British \& Foreign Bible Societies, 1976.

Kozinsky, Thaddeus J. “Alasdair MacIntyre vs. Pragmatic Liberalism,” Telos 143 (Summer, 2008): 7-21.

MacIntyre, Alasdair. After Virtue. (2 ${ }^{\text {nd }}$ Ed.) Notre Dame: University of Notre Dame Press, 1984.

MacIntyre, Alasdair. Whose Justice? Which Rationality? London: Duckworth, 1988.

MacIntyre, Alasdair. Three Rival Versions of Moral Enquiry:

Encyclopaedia, Genealogy and Tradition. Notre Dame: University of Notre Dame Press, 1990.

Smolik, Josef. "Ecumenism as Living Together." In Faith and Faithfulness: Essays on Contemporary Ecumenical Themes, edited by Pauline Webb, 61-70. Geneva: World Council of Churches, 1984.

Vosloo, Robert. "Reforming Tradition: remarks on reformed theology in South Africa, in conversation with Alasdair MacIntyre." Journal of Theology for Southern Africa 139 (March, 2010): 18-31. 